\title{
Using Data Centre Waste Heat to Dry Coffee Whilst Supplying Small-Scale Farmers With ICT: A Novel Idea and a Case Study Based on a Systems Approach
}

\author{
Petter Terenius \\ Lancaster University \\ Peter Garraghan \\ Lancaster University \\ Richard Harper \\ Lancaster University
}

\begin{abstract}
In our research, we address energy consumption of data centres, more than one per cent of the world's future electrical power. Based on a systems approach, we currently explore commodity drying using data centre waste heat, an idea here presented for the first time to the research community. Many low-and midincome countries are producing coffee, which sometimes needs mechanical drying. Using waste heat to dry coffee would be financially appealing. Conversely, if an existing drying facility may be powered by waste heat, this may call for small-scale data centre construction, in turn increasing ICT availability locally or regionally. Thus, there is a bond between environmental gains and sustainable growth of a community. We therefore investigate both environmental and societal benefits of this idea. Through a site selection based on a new index, we have chosen Costa Rica for our case study, and arrived to an estimate for its data centre waste heat drying capability. We also discuss our findings in relation to the UN Sustainable Development Goals (SDGs).
\end{abstract}

Keywords: ICT, sustainability, systems approach, coffee production, datacenter, waste heat, UN sustainable development goals, SDGs, Costa Rica, ICRI

\section{INTRODUCTION}

In light of the current climate crisis, a holistic approach to infrastructural matters regarding energy, communication, data and sustainable communities is critical, not least to address water-energy-food security challenges. One enabler for building sustainable communities around the Globe is ICT (information and communications technology). We anticipate that in the near future, because of population growth and increased relative wealth in warm parts of the world (Rosling, 2018), the number of ICT systems will expand significantly in those areas.

Through supporting data delivery and computation, data centres consume up to a few per cent of the world's electrical energy. (Masanet et al., 2020; Mujawar et al., 2018) This energy, primarily used by 
servers in the networks, ends up as dry waste heat. In cold areas, the waste heat is sometimes reused to heat buildings. (Koronen et al., 2020; Oltmanns et al., 2020) However, to our knowledge, until now, the data centre industry's opinion has been that warm countries have little use of excessive heat.

In our research, we address waste heat from these systems, to reuse up to several per cent of the world's future electrical energy, thus heavily decrease the carbon footprint of the ICT sector. The relatively low outgoing temperature of a data centre's airflow, generally $30-45^{\circ} \mathrm{C}$, makes turning heat to electricity a nonviable option, as energy conversion losses would be massive. Hence, we focus on secondary uses for dry, lukewarm air.

One theme we currently explore - here presented for the first time to the research community - involves commodity dehydration. This previously uncharted territory would not decrease energy use, but give an ability to repurpose heat to the benefit of low- and mid-income countries around the Globe. In addition to address a couple of per cent of the world's electricity use, data access and commodity dehydration are enablers for building sustainable communities.

Coffee beans are particularly attractive in this respect: coffee beans need drying to achieve moisture levels low enough for extended storage, and to avoid taste deficiencies, the airflow should preferably not exceed $45^{\circ} \mathrm{C}$. (FAO, Undated; Phillips, 1963) Moreover, coffee is often produced in humid areas, where sun-drying for partial dehydration is not possible. In either case, drying is commonly (partly or fully) carried out using diesel-, wood- or electricity-powered machinery. Given that coffee is the world's most traded commodity after oil, power needs are substantial. Indeed, as Arce et al. put it, "conventional coffee processing is energy intensive". (Arce et al., 2009)

For a community either consisting of or in the relative vicinity of some tens of thousands of inhabitants, the prospects of using data centre waste heat to dry commodities are appealing. Conversely, if the presence of a drying facility in a community may be powered by data centre waste heat, this may attract international data centre builders for both financial and CSR (corporate social responsibility) reasons, in turn increasing ICT availability locally or regionally.

Our vision is illustrated in Figure 1. Here, many farms (in this case coffee plantations) have a need for dehydration, and so, they already need to transport their undried coffee to a dryer facility. In our vision, a small data centre, consisting of servers put in a standard freight container, supply the dryer with heat. The dryer and the access to data both enable socially sustainable development of the community.

With a holistic perspective based on systems science, we are specifically investigating possible societal and environmental benefits of this solution. Most importantly, our approach gives more power to local producers of coffee: drying coffee beans close to source and then play a more active role in supply chains, may massively increase profits for local farmers or collective efforts.

\section{FIGURE 1 \\ A SYSTEMS PERSPECTIVE OF COFFEE PLANTATIONS}

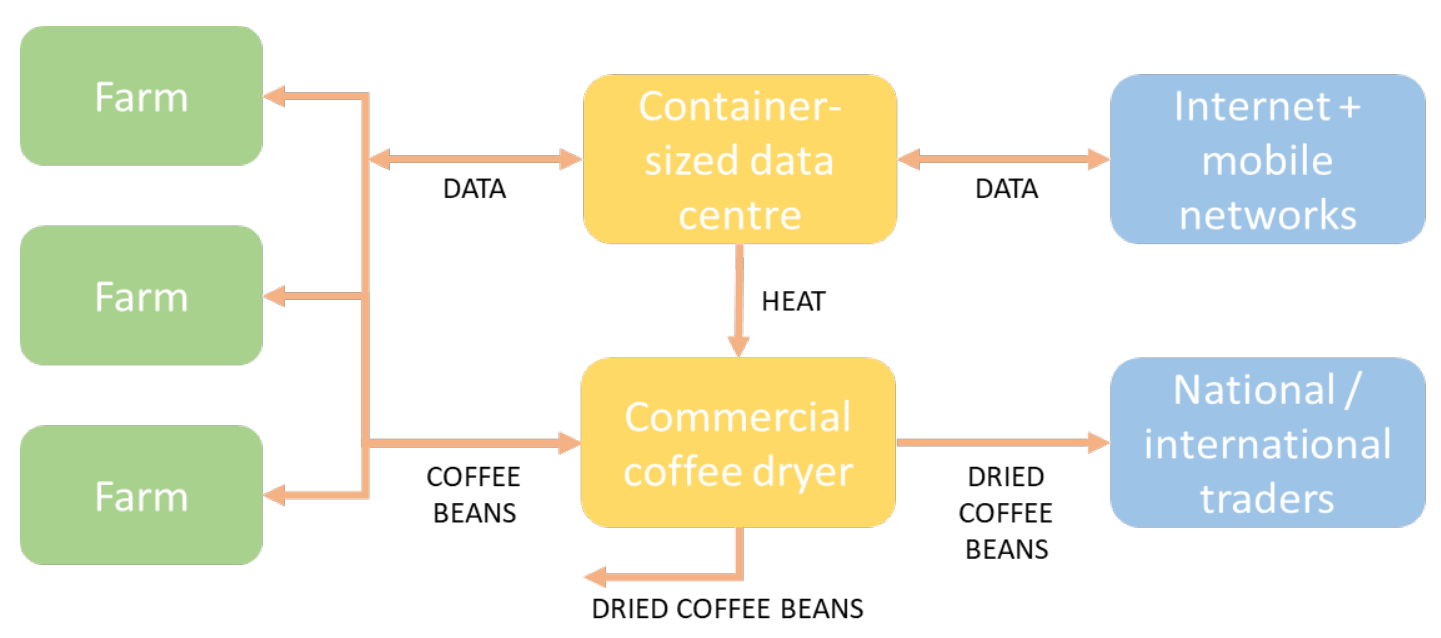




\section{METHOD}

This is a hypothesis-driven study, investigating whether data centre waste heat can provide communities with societal value, whilst simultaneously benefit the environment. The paper relies on a literature study and official statistics. Together, these form the basis for our site selection, which forms a point of departure for a discussion. As this is a position paper, there is no Results section. Instead, a discussion follows and closes the paper.

\section{Literature Study}

Our starting point has been an extensive literature study of and personal experience from data centre energy use, construction considerations, questions relating to appropriate data centre size, and the availability and capacity of existing and planned mobile networks. Due to the format, scope and aim of this paper, only small parts of this work are incorporated here.

Moreover, this paper builds on our concurrent writings on systems science and how systems science relate to the United Nation's Sustainable Development Goals, concerning low- and mid-income countries. Again, these are not presented here, due to the scope and aim of the paper.

Last, we have studied coffee production in particular, as sustainable and small-scale coffee production was decided a promising case for this research project. Selected sources from these studies are referenced here.

\section{Statistics}

For our site selection, we have relied on open-source statistics from governmental sources. Coffee production data have been retrieved from the International Coffee Organisation and the US Department of Agriculture. Additional statistics have been found in various academic papers and reports. As used, these are referenced throughout the paper.

To our knowledge, none of the statistics of this paper are controversial in nature. Further, they tend to be substantiated when reading similar sources. Thus, we see no credibility issues with the statistics at hand, at least not to the degree that this would impede our findings.

Statistics used here often lack in accuracy, mainly due to the lack of detailed statistics from the data centre industry, from low-income countries overall, and from the very different conditions under which coffee is grown and dried. However, for our findings, halting precision is not a major issue.

\section{Site Selection}

The site selection method presented here is based on concepts from systems science - the study of how entities relate to one another - and sustainability science - mainly the United Nations' Sustainable Development Goals (referred to as "the SDGs"). Using these concepts in conjunction is not far-fetched, as the SDGs are construed with a systems approach, and as the environment, social structures and the world at large can be seen from a systems perspective.

\section{ABOUT COFFEE}

The invigorating effects of coffee were discovered in Ethiopia many centuries ago, as shepherds noticed the effect coffee beans had on goats having eaten the fruits of the coffee plants. As a drink, coffee spread through Arabia and later to other parts of the world. Today, it is one of the world's most popular drinks. It is also the world's second most traded commodity, with an annual production of about 10 million tons of dried coffee beans. (International Coffee Organization, 2020)

Coffee is produced in many relatively warm regions in the world. The highest producers are listed in Table 1. Not always recognised in the literature, coffee seasons vary quite much depending on variety and growing conditions. Most coffee producing countries have a harvest season of four to six months, which would be the dry season of the country in question. 


\section{Coffee Production}

Coffee production involves several steps: planting and nursing, harvesting, drying, shipping, roasting and finally packaging and selling to consumer via retailing. The two varieties of coffee produced, Arabica and Robusta, grow under very different conditions. Arabica, the tastiest and more expensive variety, needs an altitude of at least 600 metres, whereas Robusta can be grown at sea level.

Upon harvest, the coffee cherries are sorted, pulped and finally dried (see next section). After packing, the beans can be stored for up to a year, before being traded and subsequently roasted.

Of interest here is primarily the requirement for mechanical drying. Our line of inquiry implies that there is already a suitable infrastructure in place for transporting coffee cherries, for storing them whilst awaiting transportation, et cetera.

\section{Drying Coffee}

Ripe coffee cherries are depulped so that only the beans inside remain. These are dehydrated (dried) in one of several manners, depending on location. Drying can be done mechanically or - at least to an extent - in the sun, using drying patios, drying tables etc. (Baca et al., 2014) As mentioned above, the airflow used for drying must in fact be low-temperature, preferably not over $45^{\circ} \mathrm{C}$. This is to avoid that the flavour of the coffee becomes ruined.

Coffee beans are mechanically dried in a few hours, depending on various factors: possible pre-drying, airflow heat and initial moisture content. A good overview of the coffee drying process is found in Adams \& Ghaly (2007), and a discussion of systems suitable for our purposes is found in an FAO report. (FAO, Undated) Alves et al. (2013) have found that increasing drying temperature from $35^{\circ} \mathrm{C}$ to $45^{\circ} \mathrm{C}$ and lowering the relative humidity halves the drying time.

\section{Coffee Growing Locations}

Coffee is produced in many countries, all rather close to the equator. As explained above, coffee production methods follows coffee varieties, which in turn depends on certain climates. Due to variations in climate, a regional division of coffee producing areas makes more sense than dividing them according to country. Sometimes growing conditions need a much more detailed stratification though, as shown here:

Veracruz ... accounts for 3.7\% of Mexico's total surface. Veracruz has large altitude variations: lands near the coast are flat and low, but, as distance increases from the coast, it rises up to 3,000 meters over sea level at its highest point. These altitude differences produce great diversity of climates, although most of the state (about $84 \%$ ) has a warm, humid and sub-humid climate. (Gay et al., 2006, p.261)

In short, it is not easy to give advice on a per-country basis, and this is important to keep in mind when discussing coffee production techniques.

\section{TABLE 1}

\section{COFFEE PRODUCTION ACCORDING TO GDP PER CAPITA}

\begin{tabular}{|lrrrr|}
\hline COUNTRY & 60 KG BAGS & METRIC TONS & PER CENT & GDP/C RANK \\
BRAZIL & 62906000 & 3774360 & $36,77 \%$ & 82 \\
VIETNAM & 30024000 & 1801440 & $17,55 \%$ & 121 \\
COLOMBIA & 13858000 & 831480 & $8,10 \%$ & 84 \\
INDONESIA & 10013000 & 600780 & $5,85 \%$ & 93 \\
ETHIOPIA & 7541000 & 452460 & $4,41 \%$ & 162 \\
HONDURAS & 7328000 & 439680 & $4,28 \%$ & 134 \\
INDIA & 6002000 & 360120 & $3,51 \%$ & 116 \\
\hline
\end{tabular}




\begin{tabular}{|c|c|c|c|c|}
\hline UGANDA & 4704000 & 282240 & $2,75 \%$ & 161 \\
\hline MEXICO & 4351000 & 261060 & $2,54 \%$ & 64 \\
\hline GUATEMALA & 4007000 & 240420 & $2,34 \%$ & 117 \\
\hline PERU & 4173000 & 250380 & $2,44 \%$ & 88 \\
\hline NICARAGUA & 2820000 & 169200 & $1,65 \%$ & 137 \\
\hline CÔTE D'IVOIRE & 2294000 & 137640 & $1,34 \%$ & 140 \\
\hline COSTA RICA & 1427000 & 85620 & $0,83 \%$ & 77 \\
\hline TANZANIA & 1115000 & 66900 & $0,65 \%$ & 153 \\
\hline TOTAL (ABOVE) & 162563000 & 9753780 & $95,01 \%$ & \\
\hline TOTAL (INCL OTHERS) & 171102000 & 10266120 & & \\
\hline
\end{tabular}

The coffee production figures are collected from International Coffee Organisation. They refer to the "coffee year" of 2018, stretching from 1 October 2018 to 30 September 2019. GDP per capita rankings are taken from the International Money Fund (2019). China also produces coffee, but their numbers are not easily estimated, and not included in the organisation's data. The United States Department of Agriculture, USDA (2020), estimates China's export to about 1900000 bags.

\section{COFFEE PRODUCTION AS AN ENABLER FOR SUSTAINABLE COMMUNITIES}

As mentioned above, coffee is one of the world's most traded communities. Consequently, many local communities around the world depend on coffee production.

As of the turn of this millennium, the International Coffee Organization (ICO) has viewed coffee production in terms of financial and social sustainability. Since up to 80 per cent of all farms are smallscale (Carnemark et al., 2019), building sustainable communities is in the interest of a member organisation such as the ICO. Moreover, as communities prosper, the inflow of coffee to consumer countries is constant, which in turn means the price of the coffee can be kept consistent. This too is important for the coffee business. Thus, one must rethink the old world's one-sided gain from the commodity trade (the "banana republics" comes to mind): what benefits coffee producing communities benefit everyone.

\section{Sustainable Coffee}

As noted by Carnemark et al. (2019), the market niche for sustainable coffee could be of major interest to small coffee producers, since prices can, theoretically, be kept at a premium. In fact, ICO notes that producers of sustainable coffee with both Fairtrade and Organic branding can double their income. (International Coffee Organization, 2003)

Beyond revenue, sustainable coffee also brings immediate results for the local society and environment, as shown in the Discussion section. This is not a coincidence, as despite different foci, Fairtrade, Rainforest Alliance, UTZ and similar certificates are typically recognising a holistic - or, in our view, systems based - approach to sustainability, including social, environmental and economic benefits. Interestingly, the three certificates mentioned here have not only different objectives but also different social implications, as described in Snider et al. (2017).

With a range of benefits to the society and the local environment, and with possible additional benefits to small-scale producers, the future seems bright for small producers. However, quite surprisingly, this is in stark contrast to today's reality. Sachs et al. (2019) write:

Yet coffee is experiencing a sustainability crisis, stemming from unsustainable economic, social, and environmental aspects of coffee production. The recent decline in world coffee prices has further squeezed coffee producers, and thrown a tremendous number of producers below the global extreme poverty line of US $\$ 1.90$ per day. While many consumers willingly pay high prices for coffee, coffee farmers receive a tiny fraction of that retail price. At these low farmgate prices, coffee production is not economically viable for a significant number, perhaps a majority, of coffee farmers. Sachs et al. $(2019, \mathrm{p} .4)$ 
As noted by the authors, the burden of climate change does not help, with rapidly changing weather conditions, insect infestations and so on. In short, though the world consumes 400 billion cups of coffee per year (Sachs et al., 2019), coffee producers currently experience great difficulties.

Upon reflection, it is clear there is a mismatch at play here. With consumers apparently willing to pay large sums for coffee in coffee shops, and with a steady interest in sustainability matters, what is keeping the sustainable coffee industry from flourishing? On a large scale, it may be difficult to see and understand the web of politics and pricing. One of several reasons is a "critical underinvestment, since almost zero percent of profits are re-invested in increasing sustainability of the production side of the coffee value chain". (Hivos et al., 2018) Another reason is that farms are exploited by middle-men. (Le \& Jovanovic, 2019) Our idea, empowering communities through data access, can hopefully let cooperatives work around these issues and achieve higher margins.

\section{An Enabler for Community Growth}

It should be emphasised that as localised coffee production can give additional power and income to local communities (Sachs et al., 2019), it is also an enabler for many countries. As shown in Table 1, none of the fifteen largest coffee exporters are among the top 60 countries in terms of GDP per capita. This has several implications:

1. Given the position in the charts, export of a country listed here is relatively low. Thus, successful sustainable coffee production can truly boost the country's export.

2. The world desperately needs the coming financial growth of developing countries to be environmentally sustainable. Socially and environmentally responsible coffee production can enable this growth. Indeed, one of the most important aspects of our idea is that the larger proportion of financial growth stemming from responsible commodity production, the less the proportion of other export-related activities.

3. The $80 / 20$ rule of thumb states that 20 per cent of the efforts yield 80 per cent of the results. Related to nations' export patterns, this indicates that it is much less expensive to improve efficiency in production and supply chains in developing nations than in wealthier countries, where industrial processes have been streamlined for decades. In other words, regarding sustainable commodity export in low- and mid-income countries, relatively much can be achieved with relatively little means.

4. As Popkova et al. (2018) state, "economic growth of developing countries that exceeds the growth of developed countries stimulates the reduction of disproportions in development of the world economic system". We therefore argue that the Keynesian idea of spiralling consumption as a driver for future societal and individual wellbeing must be retired. Ideally, high-income countries should now experience a few decades of zero-growth, whilst low- and mid-income countries may grow their business sectors, with a potential outcome of a more equilibrated and stable world trade. Here, sustainable production of commodities would be an attractive option.

\section{DATA CENTRES AND WASTE HEAT}

Data centres and mobile networks, complex as they may be, can still be regarded subsets of a larger, socio-technical ICT ecosystem that involves people, policies and other components on top of technology. Thus, the uses we investigate relate to purposes that empower communities as a whole.

Measuring the size of data centres for a specific country is not easy, in part due to lack of unified definitions of data centre sizes. In 2007, it was estimated that about a third of the data centre capacity in the United States was hosted in large-scale commercial, or "co-location", data centres. (Barroso et al., 2019) This was before the advent of Facebook, Netflix etc, but as the Internet giants typically do not place data centres in developing nations, we use this figure as a very crude reference for today's low- and mid-income countries.

As argued in our ongoing research, in semi-rural areas, it often makes sense to use pre-fabricated container-sized data centres including local computing and data storing capabilities, and global 
communication through integrated mobile networks. Currently, their servers use up to $50 \mathrm{~kW}$ of electrical power, eventually turning to the waste heat we hope to repurpose.

But data centres are not really about the data - what matters is the service they provide. In a low- or mid-income country, a data centre can help children attend school online, aid sick persons through online meetings with the doctor, or let a coffee plantation cooperative employee connect with distributors.

To connect to the data centre, a computer or smartphone is needed. Today, this is not much of a limitation. In fact, over five billion people have mobile phone subscriptions today. (GSM Association, 2020)

\section{SELECTION PROCESS FOR COFFEE DRYING CASE STUDY}

For our site selection, the following variables were taken in account: coffee export size, technology infrastructure and consumer needs for data, country wealth (GDP) and political stability.

\section{Coffee Export Size}

Coffee is the world's most traded commodity in need of dehydration. Therefore, for this study, we have chosen to investigate the possibilities for data centre waste heat reuse in major coffee exporting countries. Statistics show that though there are about fifty coffee-exporting countries, there is a significant gap (about fifty percent) between the last entrance in Table 1 and the next cohort. Thus, we chose between the larger ones, that is, where implementation of this idea may have bigger impact.

\section{Technology Infrastructure and Access to Data}

The idea is not only about dehydration, but to equal extent about access to data. Given the high mobile data penetration in low-and mid-income countries, we relied on data from the mobile network operator organisation GSMA to deduce an index that we refer to as the ICRI (Infrastructure/Consumer Readiness Index). By showing the gap between existing infrastructure and the IT maturity and desire for data access of the population, the point of ICRI is to show where investments in telecom - or any similar infrastructurerelated investment - make most sense.

Consequently, the aim is to identify countries, regions or local communities with low ICRI ratios, indicating that in a not too distant future, populations will demand - and have a willingness to pay for improved infrastructure. Of the selected coffee exporters, the country with the lowest ICRI turned out to be Costa Rica. This is shown in Table 2. What's interesting with ICRI is that it is not discriminating between low and high wealth. For example, Mexico has a much higher level of infrastructure than Costa Rica, and Uganda a much lower; still they both have significant higher ICRI than Costa Rica. 


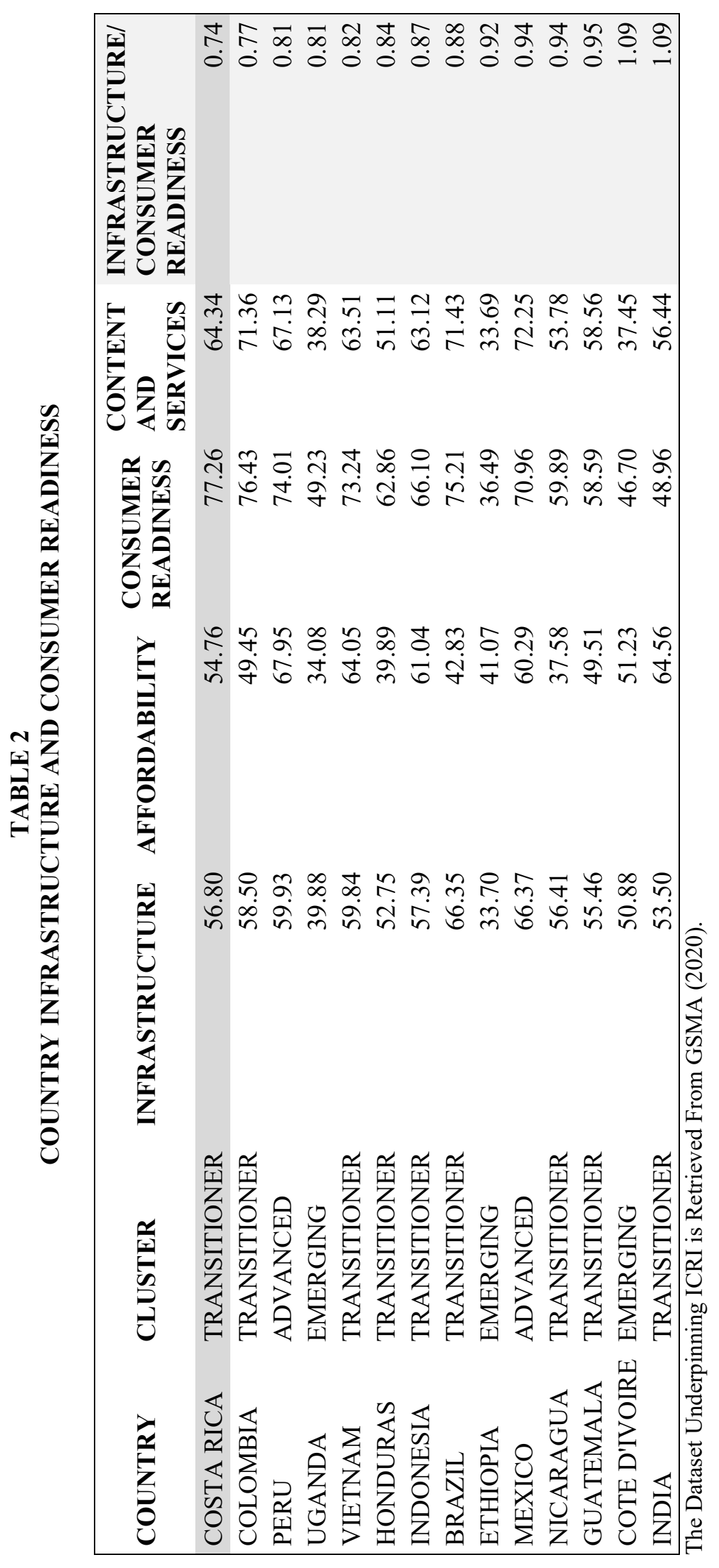




\section{Country Wealth}

Among coffee exporting countries, Mexico and Costa Rica (and China) have the highest wealth per capita. Unlike many other coffee-producing countries, the wealth of Mexico and Costa Rica has been growing steadily for several decades, as shown in Figure 2.

Furthermore, Costa Rica experiences a politically stable situation (Central Intelligence Agency, 2020) and has a rather long harvesting season (see below). Hence, though dehydration as a principle may be even more beneficial to countries with lower GDP, Costa Rica was considered a likely candidate for implementation of the ideas we propose.

\section{CASE STUDY: COSTA RICAN SMALL-SCALE COFFEE PRODUCTION COMMUNITIES}

In this section, we investigate the possible benefits of a data centre waste heat implementation for Costa Rican coffee producers. We do acknowledge that there is very likely a gap between theory and practice, as discussed below.

How much heat energy is needed to dry coffee varies significantly, depending on humidity and initial moisture content. As a consequence, figures for coffee drying must be coarse. For Costa Rica, about 275 $\mathrm{kWh}$ of electricity is needed for every ton of dried coffee. (Adams \& Ghaly, 2007) Typically, also some firewood is used, yielding about 1.5 cubic metres of burned wood per ton. (Arce et al., 2009) With an annual export of 90000 tons (International Coffee Organization, 2020), Costa Rica needs roughly $25000 \mathrm{MWh}$ and $140000 \mathrm{~m}^{3}$ of wood to dry their coffee.

As argued, we believe that for semi-rural areas in many low- and mid-income countries, the future lies in container-sized data centres. Today, they cap out at about $50 \mathrm{~kW}$, and our reference, the 40 feet FusionModule 1000A data centre from HUAWEI, needs $54 \mathrm{~kW}$ at most, in theory generating a maximum of $470000 \mathrm{kWh}$ of waste heat over a year.

\section{FIGURE 2}

\section{GDP PER CAPITA OF THE FIFTEEN BIGGEST EXPORTERS OF COFFEE}

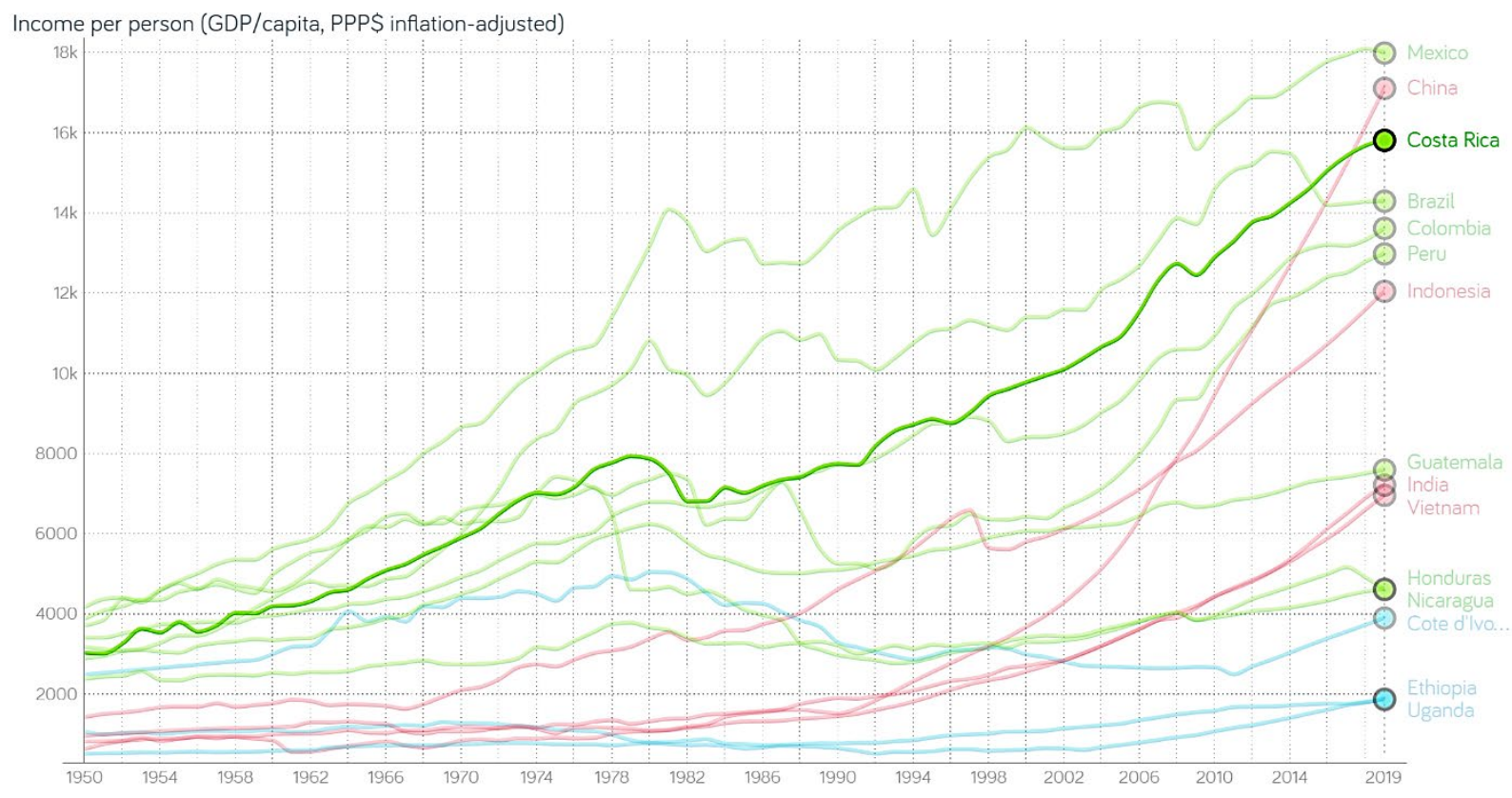

Chart created using Gapminder. Costa Rica is highlighted, and its stable economic growth since 1950 is clearly visible. Data from 1990 onwards use statistics from the World Bank, and earlier statistics come from a variety of sources. Link to the chart: https://tinyurl.com/gapmindercoffee 
This results in an ability to dry about 1700 tons of coffee each year, close to two per cent of Costa Rica's export. In other words, in theory, 50 container-sized data centres would not only be able to provide the population and tourists with access to data, but also entirely eliminate the need to power the coffee industry's dehydration processes.

In practice, the efficiency would not be as high. For one thing, a data centre would not typically be run at maximum power. Further, the calculation above assumes 24/7 drying. Therefore, the number could perhaps be divided by three or so, to give a better estimate. That said, newer server and chip technologies use higher amounts of power and higher operating temperatures, and it is likely that the energy use of a container-sized data centre will go up with time. At the time of a large-scale roll-out of our vision, it is therefore highly probable we will look at much higher values than $54 \mathrm{~kW}$. Also, it should be noted that drying takes place over several hours, so running an automatic dryer around the clock is not unreasonable.

Another matter is the fact that the harvest season in Costa Rica only lasts for about five months (depending on weather conditions). However, it should be emphasised that harvest coincides with the dry season. Logic states there would be many other uses for dehydration during the wet season, not least as coffee workers may turn to other industries at that time. (It should also be noted that many coffee workers in Costa Rica are immigrants from Nicaragua. Thus, our ideas about data access may benefit Nicaraguan workers and, in a long-term perspective, Nicaraguan communities as well.)

So how much are 50 container-sized data centres compared with the entire installed data centre capacity of Costa Rica? We have contacted the seven largest co-location data centres in Costa Rica, all placed in San José, the capital, and estimate their maximum power to $5 \mathrm{MW}$. As suggested above, we triple this figure to get all available data centre power in Costa Rica. Thus:

$$
\begin{gathered}
5 \mathrm{MW} * 3=15 \mathrm{MW} \text { total power today } \\
50 \mathrm{~kW} * 50=2.500 \mathrm{~kW}=2.5 \mathrm{MW} \text { additional power }
\end{gathered}
$$

In other words, if fully implemented, our idea would bring an additional 10-20 per cent of possible data storage and computing to Costa Rica, indicating there is likely use for these small-scale data centres. More importantly for the local community, this would move data closer to the communities, enabling computing closer to the source (called "edge computing"), hence increasing data speed and lessen the amounts of data in need of shuffling to San José or abroad.

To conclude, the figures presented here are not to be taken at face value. However, they do show the magnitude of the possibilities for repurposing data centre waste heat in a warm country, an idea presented here for the first time.

\section{DISCUSSION}

Due to the complexity of this project, it is too early to say to what extent data centre waste heat can indeed be used under the specific circumstances mentioned above. Still, as coffee production is achieved in different manners depending on topography, humidity, social structures, legislation and tradition, we are confident this innovative approach has merit in many developing country contexts.

Coffee producers play a big role in today's world. An industry employing sixty million people (Sachs et al., 2019) and delivering ten billion kilos of produce to the global market yearly, coffee production should be able to have a substantial impact on consumption, values, and climate, thus responding to the demands of many of the UN SDGs (see Table 3; for brevity, only a few examples are given). This is particularly valid if lessons learned from the coffee production sector are used in other places in the commodity sector, say tea and cocoa production, thereby tripling the societal and environmental impacts.

The fact that sustainable coffee connects to several of the UN SDGs has not gone unnoticed by the ICO:

Higher coffee prices are associated with more rural employment, higher contribution of agriculture to GDP, lower levels of poverty (SDG 1), increased food security (SDG 2), 
reduced inequality (SDG 10), and higher political stability (SDG 16). Hence, policies that help to increase and stabilise income levels of coffee-producing households can have a significant impact on economic and social development [...]. (International Coffee Organization, 2019, p.12)

Further, Sachs et al. (2019) connect fourteen of the SDGs to the coffee production sector, omitting only SDGs 10, 11 and 14. It is promising that SDG 11 - Sustainable communities - is where our idea contributes the most, thus extending the value of those authors' research.

Last, it is noteworthy that whereas Sachs et al. pinpoint problems relating to the SDGs, we look at solutions. It would be interesting to see in what way problem can meet solution, in a later research context.

\section{Limitations and Propositions for Further Research}

Due to the extraordinary circumstances for travelling during 2020, undertaking field work has not been possible. We see this limitation as an incentive for future work, as indeed an ethnographic study of agriculture and ecotourism in Costa Rica would most certainly provide additional insights. As suggested in the literature (Howitt \& Mason, 2018), agriculture and ecotourism can provide communities with higher, and complimentary, income. Costa Rica is an attractive location for tourism. Conversely, tourism is financially important to Costa Rica, indicated by the fact that whilst agriculture employs 14 per cent of the country's workforce, and industry 22 per cent, services (including tourism) employs a much higher 64 per cent. (Howitt \& Mason, 2018) A field study could not only explore this relationship but also improve dehydration metrics for the specific environmental conditions.

TABLE 3

OUR VISION RELATED TO THE UN SDGS

\begin{tabular}{|c|c|c|c|}
\hline SDG & THEME & RELEVANCE & COMMENT/EXAMPLE OF CONTRIBUTION \\
\hline 1 & NO POVERTY & HIGH & $\begin{array}{l}\text { DATA ACCESS ENABLES EDUCATION AND } \\
\text { TRADE. COFFEE DRYING GENERATES } \\
\text { FINANCIAL GROWTH. }\end{array}$ \\
\hline 2 & ZERO HUNGER & HIGH & $\begin{array}{l}\text { MAY BE INCREASED IF OTHER } \\
\text { COMMODITIES ARE DEHYDRATED DURING } \\
\text { THE WET SEASON. ALSO AN ENABLER OR } \\
\text { FOOD SECURITY. }\end{array}$ \\
\hline 3 & $\begin{array}{l}\text { GOOD HEALTH } \\
\text { AND WELL-BEING }\end{array}$ & LOW & SEE ABOVE. \\
\hline 4 & $\begin{array}{l}\text { QUALITY } \\
\text { EDUCATION }\end{array}$ & HIGH & $\begin{array}{l}\text { DATA ACCESS ENABLES VIRTUAL } \\
\text { CLASSROOMS AND LECTURES AFTER } \\
\text { PLANTATION WORK. }\end{array}$ \\
\hline 5 & GENDER EQUALITY & HIGH & $\begin{array}{l}\text { OUR VISION ENABLES COOPERATIVES, } \\
\text { OFTEN RUN BY WOMEN. IN ADDITION, IT } \\
\text { HAS BEEN SHOWN THAT AT COFFEE } \\
\text { PLANTATIONS, GENDER EQUALITY SUFFERS } \\
\text { DURING FINANCIAL UNSTABLE TIMES. } \\
\text { (ECHEVERRÍA, 2020) }\end{array}$ \\
\hline 6 & $\begin{array}{l}\text { CLEAN WATER } \\
\text { AND SANITATION }\end{array}$ & LOW & \\
\hline 7 & $\begin{array}{l}\text { AFFORDABLE AND } \\
\text { CLEAN ENERGY }\end{array}$ & VERY HIGH & $\begin{array}{l}\text { THE IDEA BRINGS FREE HEAT ENERGY TO } \\
\text { COFFEE PLANTATIONS. }\end{array}$ \\
\hline
\end{tabular}




\begin{tabular}{|c|c|c|c|}
\hline 8 & $\begin{array}{l}\text { DECENT WORK } \\
\text { AND ECONOMIC } \\
\text { GROWTH }\end{array}$ & VERY HIGH & $\begin{array}{l}\text { ONE OF THE MAIN POINTS OF OUR VISION IS } \\
\text { TO ENABLE SUSTAINABLE ECONOMIC } \\
\text { GROWTH. }\end{array}$ \\
\hline 9 & $\begin{array}{l}\text { INDUSTRY, } \\
\text { INNOVATION AND } \\
\text { INFRASTRUCTURE }\end{array}$ & VERY HIGH & $\begin{array}{l}\text { THROUGH A HOLISTIC PERSPECTIVE ON } \\
\text { INFRASTRUCTURE, SMALL INDUSTRIES } \\
\text { (ALSO OTHER THAN COFFEE) AND THE } \\
\text { COMMUNITY ITSELF MAY FLOURISH. }\end{array}$ \\
\hline 10 & $\begin{array}{l}\text { REDUCED } \\
\text { INEQUALITIES }\end{array}$ & $\mathrm{HIGH}$ & $\begin{array}{l}\text { BY SUPPLYING A COMMUNITY OR A } \\
\text { COOPERATIVE WITH A SMALL-SCALE MULTI- } \\
\text { PURPOSE DATA CENTRE/DEHYDRATION } \\
\text { FACILITY, THEREBY CUTTING THE } \\
\text { MIDDLEMEN OUT, A LARGER SHARE OF THE } \\
\text { MONEY CAN STAY AT THE SOURCE. }\end{array}$ \\
\hline 11 & $\begin{array}{l}\text { SUSTAINABLE } \\
\text { CITIES AND } \\
\text { COMMUNITIES }\end{array}$ & VERY HIGH & $\begin{array}{l}\text { THE UNDERLYING IDEA IS TO ACHIEVE } \\
\text { SUSTAINABLY BUILT COMMUNITIES. }\end{array}$ \\
\hline 12 & $\begin{array}{l}\text { RESPONSIBLE } \\
\text { CONSUMPTION } \\
\text { AND PRODUCTION }\end{array}$ & $\mathrm{HIGH}$ & $\begin{array}{l}\text { COFFEE DRYING IS ENERGY INTENSIVE. } \\
\text { REUSING HEAT ENERGY MAKES PERFECT } \\
\text { SENSE FOR SUSTAINABLE COFFEE } \\
\text { PRODUCTION. }\end{array}$ \\
\hline 13 & CLIMATE ACTION & $\mathrm{HIGH}$ & $\begin{array}{l}\text { SEEN IN A LARGER PERSPECTIVE, } \\
\text { DEHYDRATION THROUGH DATA CENTRE } \\
\text { WASTE HEAT DIRECTLY ADDRESSES ABOUT } \\
2 \% \text { OF THE WORLD'S ELECTRICAL ENERGY } \\
\text { CONSUMPTION. }\end{array}$ \\
\hline 14 & $\begin{array}{l}\text { LIFE BELOW } \\
\text { WATER }\end{array}$ & NONE & $\begin{array}{l}\text { (WHEN APPLIED TO COFFEE DRYING } \\
\text { SPECIFICALLY) }\end{array}$ \\
\hline 15 & LIFE ON LAND & LOW/MEDIUM & $\begin{array}{l}\text { IF ENERGY IS REUSED AND SAVES WOOD, } \\
\text { FORESTS MAY BE SAVED. }\end{array}$ \\
\hline 16 & $\begin{array}{l}\text { PEACE, JUSTICE } \\
\text { AND STRONG } \\
\text { INSTITUTIONS }\end{array}$ & LOW & $\begin{array}{l}\text { OUR VISION IS NOT RELATED TO SDG } 16, \\
\text { MORE THAN INDIRECTLY THROUGH PEACE } \\
\text { BROUGHT THROUGH STRONGER SOCIETIES. }\end{array}$ \\
\hline 17 & $\begin{array}{l}\text { PARTNERSHIP FOR } \\
\text { THE GOALS }\end{array}$ & LOW/MEDIUM & $\begin{array}{l}\text { THE IDEA ADDRESSES 17.6-17.8 } \\
\text { (TECHNOLOGY COOPERATION) AND } 17.11 \\
\text { (ENABLING EXPORT INCREASE OF } \\
\text { DEVELOPING COUNTRIES). }\end{array}$ \\
\hline
\end{tabular}

In this paper, we have taken for granted that export is an enabler for developing nations. Popkova et al. (2018) make an interesting case when showing how inefficiently the export trade currently affects lowincome country economies. In brief, they argue that export often does not bring with it additional effects on the economies, due to inefficient social and financial structures. Be that as it may, export is still a key enabler to sound financial situations, and the fact that export can probably be more efficiently used as a catalyst towards economic growth does not mean increased export is not to be sought after for low- and mid-income countries.

\section{CONCLUSIONS}

In our research, we aim to contribute to sustainable communities and an improved environment through ICT. The calculations presented here and the UN SDG chart both indicate potential for the proposed solution. 
We acknowledge there are still obstacles to overcome, quirks to work out and matters to yet understand, but what if our vision could be fulfilled? What if a holistic perspective on small-scale sustainable coffee production could pave the way for the commodity sector as a whole, pushing for an environmentally and socially viable food chain throughout the world?

It is our hope that integrating ICT in coffee communities and looking at coffee communities with a systems perspective can enable this change.

\section{REFERENCES}

Adams, M., \& Ghaly, A. (2007). Maximizing sustainability of the Costa Rican coffee industry. Journal of Cleaner Production, 15(17), 1716-1729.

Alves, G.E., Isquierdo, E.P., Borém, F.M., Siqueira, V.C., Oliveira, P.D., \& Andrade, E.T. (2013). Drying kinetics of natural coffee for different temperatures and low relative humidity. Coffee Science, 8(2), 238-247.

Arce, V.J.C., Raudales, R., Trubey, R., King, D.I., Chandler, R.B., \& Chandler, C.C. (2009). Measuring and managing the environmental cost of coffee production in Latin America. Conservation and Society, 7(2), 141-144.

Baca, M., Läderach, P., Haggar, J., Schroth, G., \& Ovalle, O. (2014). An integrated framework for assessing vulnerability to climate change and developing adaptation strategies for coffee growing families in Mesoamerica. PloS One, 9(2).

Barroso, L.A., Hölzle, U., \& Ranganathan, P. (2019). The Datacenter as a Computer: Designing Warehouse-Scale Machines (Third Edition). Morgan \& Claypool.

Carnemark, M., Baum, L., Partin, D., \& Tian, K. (2019). Implications of Specialty Coffee Farming Costs in Colombia.

Central Intelligence Agency. (2020). The World Factbook: Central America:: Costa Rica. Retrieved July 3, 2020, from https://www.cia.gov/library/publications/the-world-factbook/geos/cs.html

Echeverría, C.C. (2020). Gender and Climate Change in Smallholder Family Farms of Tierra Blanca, Carthago. In R. Fletcher, B. Dowd-Uribe, \& G.A. Aistara (Eds.), The Ecolaboratory:

Environmental Governance and Economic Development in Costa Rica. University of Arizona Press.

FAO. (n.d.). Good Hygiene Practices along the coffee chain.

Gay, C., Estrada, F., Conde, C., Eakin, H., \& Villers, L. (2006). Potential impacts of climate change on agriculture: a case of study of coffee production in Veracruz, Mexico. Climatic Change, 79(3-4), 259-288.

GSM Association. (2020). Data - GSMA Intelligence. Retrieved July 15, 2020.

Hivos, Solidaridad, Conservation International, COSA, Oxfam Worldshops, \& SAFE Platform. (2018). Coffee Barometer 2018. Retrieved from https://www.hivos.org/assets/2018/06/Coffee-Barometer2018.pdf

Howitt, J., \& Mason, C.W. (2018). Ecotourism and sustainable rural development in Pérez Zeledón, Costa Rica. Journal of Rural and Community Development, 13(1).

International Coffee Organization. (2003). Sustainable Coffee Executive Summary.

International Coffee Organization. (2019). Coffee Development Report 2019: Growing for prosperity.

International Coffee Organization. (2020). Coffee Production Report April 2020. Retrieved from $\mathrm{http}: / /$ www.ico.org/trade_statistics.asp?section=Statistics

International Money Fund. (2019). World Economic Outlook Database October 2019. World Economic Outlook Database October 2019. Retrieved July 8, 2020, from

https://www.imf.org/external/pubs/ft/weo/2019/02/weodata/index.aspx

Koronen, C., Åhman, M., \& Nilsson, L.J. (2020). Data centres in future European energy systems energy efficiency, integration and policy. Energy Efficiency, 13(1), 129-144. 
Le, Q., \& Jovanovic, G. (2019). From crisis to specialty coffee: The Case of Nicaraguan Smallholder Cooperatives and Jesuit Business Education for Sustainability and Justice. Journal of Management for Global Sustainability, 7(1).

Masanet, E., Shehabi, A., Lei, N., Smith, S., \& Koomey, J. (2020). Recalibrating global data center energy-use estimates. Science, 367(6481), 984-986.

Mujawar, A., Krishnan, S.S., Kumar, S., \& Sawant, A. (2018). IoT: Green Data Center Strategies. International Journal on Future Revolution in Computer Science \& Communication Engineering, 4(5), 170-174.

Oltmanns, J., Sauerwein, D., Dammel, F., Stephan, P., \& Kuhn, C. (2020). Potential for waste heat utilization of hot-water-cooled data centers: A case study. Energy Science \& Engineering, 8(5), 1793-1810.

Phillips, A.L. (1963). A solar-energy method for reducing coffee-drying costs. The Journal of Agriculture of the University of Puerto Rico, 47(4), 226-235.

Popkova, E.G., Bogoviz, A.V., Pozdnyakova, U.A., \& Przhedetskaya, N.V. (2018). Specifics of economic growth of developing countries. In Management of Changes in Socio-Economic Systems (pp. 139-146). Springer.

Rosling, H. (2018). Factfulness: Ten Reasons We're Wrong About The World-And Why Things Are Better Than You Think. Sceptre.

Sachs, J.D., Cordes, K.Y., Rising, J., Toledano, P., \& Maennling, N.W. (2019). Ensuring Economic Viability \& Sustainability of Coffee Production.

Snider, A., Gallegos, A.A., Gutiérrez, I., \& Sibelet, N. (2017). Social capital and sustainable coffee certifications in Costa Rica. Human Ecology, 45(2), 235-249.

United States Department of Agriculture. (2020). Coffee: World Markets and Trade. Retrieved from https://apps.fas.usda.gov/psdonline/circulars/coffee.pdf 